\title{
PENGARUH I-BRANDING PADA WEBSITE BINUS UNIVERSITY TERHADAP LOYALITAS PELANGGAN
}

\author{
Meyliana; Henry Antonius E.W.; Stephen W. Santoso \\ Information Systems Department, School of Information Systems, Binus University \\ Jl. K.H. Syahdan No. 9, Palmerah, Jakarta Barat 11480 \\ meyliana@binus.edu; haew@binus.edu; ssantoso@binus.edu
}

\begin{abstract}
Implementing an appropriate branding strategy supports a company in putting its product or service to be customers' top of mind. Aligned with the development of information technology, especially the Internet, merging branding with internet (i-branding) creates a unique characteristic for a company. It is very helpful for a company in competing in the free market. Therefore, it is important for a company to know information about customer perception in assessing i-branding that has been applied to its website. As an educational institution which is a pioneer in the use of information technology, Binus University concerns much about its branding on the official website (www.binus.ac.id). This study is conducted to assess the i-branding of Binus University on the point of view of its students as customers. This study uses Four Pillars of i-branding consisting the following variables: customer understanding, marketing communication, interactivity, content, and customer loyalty consisting of trust and satisfaction. The hypothesis is tested by correlation analysis and regression analysis. Based on correlation analysis, all hypotheses of $\mathrm{H1}$ (no relation) is received and based on regression analysis, all hypotheses of $\mathrm{H1}$ (bring effects) is received.
\end{abstract}

Keywords: i-branding, four pillars of i-branding, trust, satisfaction, customer loyalty

\begin{abstract}
ABSTRAK
Penerapan strategi branding yang tepat membantu perusahaan menempatkan produk atau jasa yang dijualnya menjadi top of mind di benak pelanggan. Selaras dengan perkembangan teknologi informasi yang semakin pesat terutama internet, penggabungan branding dengan internet (i-branding) menciptakan karakteristik unik bagi perusahaan yang sulit ditiru oleh para pesaing. Hal ini sangat membantu perusahaan dalam berkompetisi di era pasar bebas. Maka dari itu, penting bagi perusahaan untuk mengetahui informasi tentang persepsi pelanggan dalam menilai i-branding yang sudah diterapkan pada websitenya. Sebagai sebuah institusi pendidikan yang menjadi pelopor dalam penggunaan teknologi informasi, BINUS University sangat memperhatikan branding pada situs resminya (www.binus.ac.id). Penelitian ini dilakukan untuk menilai ibranding yang dilakukan BINUS University dari kaca mata mahasiswanya selaku pelanggan. Metode penelitian menggunakan model Four Pillars of i-Branding yang terdiri atas variabel understanding customer, marketing communication, interactivity, content, dan Customer Loyalty yang terdiri atas trust dan satisfaction. Hipotesisnya diuji berdasarkan análisis korelasi dan análisis regresi. Berdasarkan análisis korelasi, semua hipotesis H1 (ada hubungan) diterima dan berdasarkan análisis regresi, semua hipotesis H1 (berpengaruh) diterima.
\end{abstract}

Kata kunci: i-branding, four pillars of i-branding, trust, satisfaction, customer loyalty 


\section{PENDAHULUAN}

Persaingan bisnis yang semakin kompetitif menuntut perusahaan harus menerapkan strategi marketing yang tepat dan benar. Perusahaan harus dapat menempatkan merek produk atau jasa yang dijualnya di dalam benak pelanggan. Sebuah merek produk atau jasa yang mudah diingat oleh pelanggan, akan membuat pelanggan mencari merek tersebut apabila membutukan produk atau jasa tersebut. Karena itu, perusahaan harus mencari cara agar produk atau jasa yang dijualnya menjadi top of mind dalam benak pelanggan. Konsep inilah yang dikenal dengan istilah branding. Branding merupakan proses penciptaan sebuah nilai dengan memberikan pengalaman terhadap pelanggan dengan sesuatu yang menarik dan konsisten untuk memuaskan pelanggan dan membuat mereka datang kembali (Aaker, 1991; De Chernatony \& McDonald, 1992). Pelanggan mengembangkan kepercayaan terhadap brand melalui kepuasan dan pengalaman dari pengguna, karena itu perusahaan dapat membangun hubungan yang lebih erat dengan pengguna, dengan cara memperkuat brand dan membuat brand lebih sulit ditiru bagi kompetitor (Doyle, 1998).

Dewasa ini perkembangan teknologi informasi terutama internet sangat pesat dan fenomenal. Perusahaan harus mendefinisikan ulang strategi pemasaran dan branding untuk menciptakan karakteristik unik dari penggabungan branding dan internet (Ibeh, et al., 2005), yang kemudian dikenal dengan istilah i-branding. Kenney and Curry (1999) menjelaskan tentang penciptaan karakteristik terhadap pengalaman dari pelanggan secara online memiliki dampak yang sangat penting bagi suatu perusahaan. Untuk itulah, Simmons (2007) mengembangan sebuah model dalam i-branding yang disebut dengan Four Pillars of i-Branding yang terdiri dari understanding customer, marketing communication, interactivity dan content. Sebagai sebuah institusi pendidikan yang menjadi pelopor dalam penggunaan teknologi informasi, BINUS University sangat memperhatikan branding pada situs resminya (www.binus.ac.id). Penelitian ini dilakukan untuk menilai $i$-branding yang sudah dilakukan BINUS University dari kaca mata mahasiswanya selaku pelanggan yang dapat merekomendasikan BINUS University kepada teman, kerabat dan sanak saudaranya. Tujuan penelitian ini untuk mengetahui sejauh mana pengaruh i-branding pada website BINUS University yang dirasakan mahasiswa akan mempengaruhi loyalitas mereka terutama dalam hal kepercayaan dan kepuasan mereka sebagai pelanggan BINUS University. Sedangkan manfaat yang didapat dengan penelitian ini adalah memberikan informasi kepada BINUS University tentang hal-hal yang mempengaruhi $i$ branding pada website terhadap loyalitas pelanggan dan memberikan rekomendasi untuk melakukan perbaikan-perbaikan ke depannya agar website BINUS University dapat membantu meningkatkan loyalitas pelanggan.

\section{METODE}

Metodologi penelitian yang digunakan dapat dilihat pada Gambar 1 berikut.

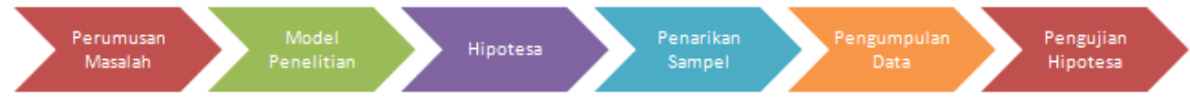

Gambar 1 Metodologi penelitian

Perumusan masalahnya adalah apakah i-branding yang dijabarkan oleh variabel understanding customer, marketing communication, interactivity, dan content memiliki hubungan dan pengaruh yang signifikan dengan customer loyalty yang dijabarkan oleh variabel trust \& satisfaction..

Model peneltian dapat dilihat pada Gambar 2 berikut. Berdasarkan Anderson \& Swaminathan 
(2011) dan Simmons (2007), terdapat beberapa variable yang telah teruji validitas, reliabilitas, korelasi dan regresi-nya, sehingga variabel tersebut dapat digunakan kembali pada penelitian ini. Variabelvariabel yang digunakan pada penelitian ini berguna untuk mengetahui apakah ada tidaknya hubungan (korelasi) dan pengaruh (regresi) antara satu variabel terhadap variabel lainnya khususnya mengenai $i-$ branding melalui website BINUS University (www.binus.ac.id) terhadap loyalitas pelanggan. Detil penjelasan tiap variabel dapat dilihat pada Tabel 1.

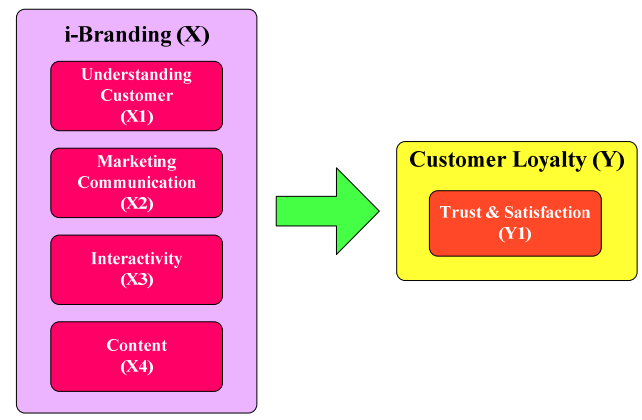

Gambar 2 Model penelitian

Tabel 1 Penjelasan Tiap Variabel

\begin{tabular}{|c|c|c|}
\hline Nama variabel & Nama sub variabel & Penjelasan \\
\hline \multirow{7}{*}{$\begin{array}{l}\text { Understanding } \\
\text { Customer } \\
\text { (X1) }\end{array}$} & & Tampilan situs mengerti customer \\
\hline & Jangkauan akses (X1.1) & Memiliki jangkauan yang dapat diakses secara global \\
\hline & Tampilan fleksibel (X1.2) & Memiliki tampilan yang fleksibel \\
\hline & Response time (X1.3) & Memiliki response time yang cepat \\
\hline & Inovasi teknologi (X1.4) & Memiliki inovasi terhadap teknologi \\
\hline & Kenyamanan (X1.5) & Memberikan kenyamanan dalam mengakses situs \\
\hline & Navigasi (X1.6) & Memiliki navigasi untuk mempercepat perpindahan menu \\
\hline \multirow{8}{*}{$\begin{array}{c}\text { Marketing } \\
\text { Communication } \\
\text { (X2) }\end{array}$} & & Situs memiliki marketing komunikasi yang menarik \\
\hline & Banner ads /iklan (X2.1) & Memiliki banner ads / iklan yang menarik \\
\hline & Tampilan menarik (X2.2) & Memiliki tampilan yang menarik \\
\hline & $\begin{array}{l}\text { Pencantuman alamat situs } \\
(\mathrm{X} 2.3)\end{array}$ & $\begin{array}{l}\text { Selalu mencantumkan alamat situs BINUS ( www.binus.ac.id ) pada } \\
\text { berbagai media promosi }\end{array}$ \\
\hline & $\begin{array}{l}\text { Brand /merek yang } \\
\text { terpercaya }(\mathrm{X} 2.4)\end{array}$ & Memiliki nama brand / merek yang terpercaya \\
\hline & Kemudahan berdialog (X2.5) & $\begin{array}{l}\text { Memberikan kemudahan untuk berdialog dalam email, chat room, } \\
\text { newsgroup kepada pengguna }\end{array}$ \\
\hline & Pemberian informasi (X2.6) & Memberikan informasi yang memuaskan \\
\hline & Penyediaan email (X2.7) & Menyediakan email yang dapat digunakan oleh pengguna \\
\hline \multirow{4}{*}{$\begin{array}{l}\text { Interactivity } \\
\qquad(\mathrm{X} 3)\end{array}$} & & Situs memberikan kesempatan dalam berinteraktif \\
\hline & Penyediaan blog (X3.1) & Menyediakan blogs yang bermanfaat bagi pengguna \\
\hline & $\begin{array}{l}\text { Penyediaan RSS Feeds } \\
(\mathrm{X} 3.2)\end{array}$ & $\begin{array}{l}\text { Menyediakan RSS Feeds / mengirim informasi terbaru yang } \\
\text { bermanfaat untuk pengguna }\end{array}$ \\
\hline & $\begin{array}{l}\text { Online Communities / } \\
\text { Social Network (X3.3) }\end{array}$ & Memiliki online communities / social network \\
\hline \multirow{5}{*}{$\begin{array}{l}\text { Content } \\
\text { (X4) }\end{array}$} & & $\begin{array}{l}\text { Bagaimana konten suatu situs menyediakan informasi yang berguna } \\
\text { bagi pengguna }\end{array}$ \\
\hline & \begin{tabular}{|l|} 
Informasi yang tepat $(\mathrm{X} 4.1)$ \\
\end{tabular} & Memberikan informasi yang tepat \\
\hline & Informasi yang sesuai (X4.2) & Menyediakan informasi yang sesuai dengan kebutuhan pengguna \\
\hline & $\begin{array}{l}\text { Fitur pencarian informasi } \\
(\mathrm{X} 4.3)\end{array}$ & $\begin{array}{l}\text { Menyediakan fitur-fitur yang mendukung proses pencarian informasi } \\
\text { yang diperlukan }\end{array}$ \\
\hline & $\begin{array}{l}\text { Informasi yang memadai } \\
(\mathrm{X} 4.4)\end{array}$ & Memberikan informasi yang memadai \\
\hline \multirow{3}{*}{$\begin{array}{c}\text { Trust \& } \\
\text { Satisfaction } \\
\text { (Y1) }\end{array}$} & Kepuasan (Y1.1) & Kepuasan terhadap situs www.binus.ac.id \\
\hline & Kepercayaan (Y1.2) & Kepercayaan terhadap situs www.binus.ac.id \\
\hline & Rekomendasi (Y1.3) & $\begin{array}{l}\text { Merekomendasikan BINUS University kepada teman, kerabat dan } \\
\text { sanak saudara }\end{array}$ \\
\hline
\end{tabular}


Hipotesis disusun menjadi delapan hipotesis berdasarkan analisis korelasi (hipotesis 1 - hipotesis 4) dan analisis regresi berganda (hipotesis 5 - hipotesis 8), yaitu:

Hipotesis 1:

H0: Understanding customer tidak berhubungan dengan Trust \& Satisfaction.

H1: Understanding customer berhubungan dengan Trust \& Satisfaction.

Hipotesis 2:

H0: Marketing Communication tidak berhubungan dengan Trust \& Satisfaction.

H1: Marketing Communication berhubungan dengan Trust \& Satisfaction.

Hipotesis 3:

H0: Interactivity tidak berhubungan dengan Trust \& Satisfaction.

H1: Interactivity berhubungan dengan Trust \& Satisfaction.

Hipotesis 4:

H0: Content tidak berhubungan dengan Trust \& Satisfaction.

H1: Content berhubungan dengan Trust \& Satisfaction.

Hipotesis 5:

H0: Understanding customer tidak memiliki pengaruh dengan Trust \& Satisfaction..

H1: Understanding customer memiliki pengaruh dengan Trust \& Satisfaction.

Hipotesis 6:

H0: Marketing Communication tidak memiliki pengaruh dengan Trust \& Satisfaction.

H1: Marketing Communication memiliki pengaruh dengan Trust \& Satisfaction.

Hipotesis 7:

H0: Interactivity tidak memiliki pengaruh dengan Trust \& Satisfaction.

H1: Interactivity memiliki pengaruh dengan Trust \& Satisfaction.

Hipotesis 8:

H0: Content tidak memiliki pengaruh dengan Trust \& Satisfaction.

H1: Content memiliki pengaruh dengan Trust \& Satisfaction.

Analisis korelasi dilakukan untuk melihat apakah ada hubungan antara varibel bebas dan variabel terikat dan korelasi ini dilakukan menggunakan teknik korelasi product moment, yang rumusnya data dijelaskan sebagai berikut (Sugiyono, 2008).

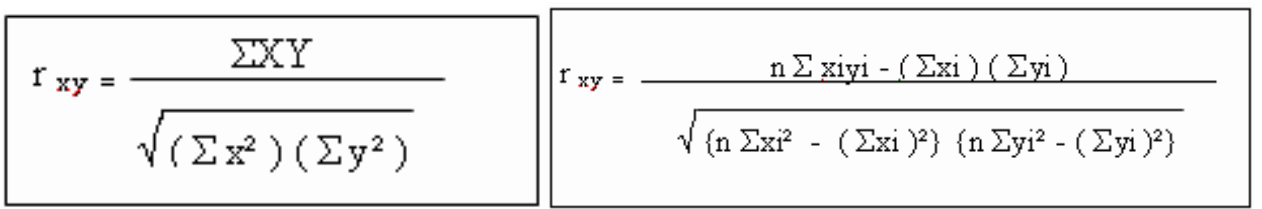

Keterangan:

$\mathrm{R}=$ Koefisien korelasi

$\mathrm{xi}=$ Jumlah variabel $\mathrm{X}$

yi $=$ Jumlah variabel Y

$\mathrm{n}=$ Jumlah Sampel

Sedangkan analisis regresi berganda dilakukan untuk menguji apakah variabel bebas memiki pengaruh atau dampak terhadap variabel terikat dan berapa besar pengaruh tersebut. Bentuk persamaan regresi: $Y^{\prime}=a+b X$, di mana

$\mathrm{Y}^{\prime}=$ subyek dalam variabel dependen yang diprediksikan 
$\mathrm{a}=$ harga $\mathrm{Y}$ bila $\mathrm{X}=0$ (harga konstan)

$\mathrm{b}=$ angka arah atau koefisien regresi, yang menunjukkan angka

$\mathrm{X}=$ subyek pada variabel independen yang mempunyai nilai tertentu.

Peningkatan ataupun penurunan variabel terikat yang didasarkan pada variabel bebas. Bila $b(+)$, akan terjadi kenaikan. Bila $b(-)$, akan terjadi penurunan (Sugiyono, 2008).

Untuk melihat hal-hal yang harus ditingkatkan pada i-branding website BINUS University, kami menggunakan gap analisis dengan metode IPA (importance performance analysis). Metode IPA pertama kali diperkenalkan oleh Martilla dan James pada tahun 1977 dengan tujuan untuk mengukur hubungan antara persepsi konsumen dan prioritas peningkatan kualitas produk/ jasa yang dikenal pula sebagai quadrant analysis (Brandt, 2000 dan Latu \& Everett, 2000). IPA telah diterima secara umum dan dipergunakan pada berbagai bidang kajian karena kemudahan untuk diterapkan dan tampilan hasil analisis yang memudahkan usulan perbaikan kinerja (Martinez, 2003). IPA mempunyai fungsi utama untuk menampilkan informasi berkaitan dengan faktor-faktor pelayanan yang menurut konsumen sangat mempengaruhi kepuasan dan loyalitas mereka, dan faktor-faktor pelayanan yang menurut konsumen perlu ditingkatkan karena kondisi saat ini belum memuaskan.

IPA menggabungkan pengukuran faktor tingkat kepentingan dan tingkat kepuasan dalam grafik dua dimensi yang memudahkan penjelasan data dan mendapatkan usulan praktis. Interpretasi grafik IPA sangat mudah, di mana grafik IPA dibagi menjadi empat buah kuadran berdasarkan hasil pengukuran sebagaimana terlihat pada Gambar 3.

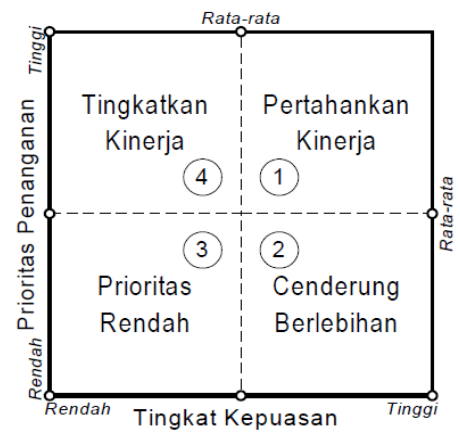

Gambar 3 Pembagian kuadran importance performance analysis

Berikut penjelasan untuk masing-masing kuadran menurut Brandt (2000). Kuadran Pertama adalah "pertahankan kinerja" (high importance \& high performance). Faktor-faktor yang terletak pada kuadran ini dianggap sebagai faktor penunjang bagi kepuasan konsumen sehingga pihak manajemen berkewajiban memastikan bahwa kinerja institusi yang dikelolanya dapat terus mempertahankan prestasi yang telah dicapai. Kuadran kedua adalah "cenderung berlebihan" (low importance \& high performance). Faktor-faktor yang terletak pada kuadran ini dianggap tidak terlalu penting sehingga pihak manajemen perlu mengalokasikan sumber daya yang terkait dengan faktor-faktor tersebut kepada faktor-faktor lain yang mempunyai prioritas penanganan lebih tinggi yang masih membutuhkan peningkatan, semisal dikuadran keempat. Kuadran ketiga adalah "prioritas rendah" (low importance \& low performance). Faktor-faktor yang terletak pada kuadran ini mempunyai tingkat kepuasan yang rendah dan sekaligus dianggap tidak terlalu penting bagi konsumen, sehingga pihak manajemen tidak perlu memprioritaskan atau terlalu memberikan perhatian pada faktor -faktor tersebut. Kuadran keempat adalah "tingkatkan kinerja" (high importance \& low performance). Faktorfaktor yang terletak pada kuadran ini dianggap sebagai faktor yang sangat penting oleh konsumen. Namun kondisi pada saat ini belum memuaskan sehingga pihak manajemen berkewajiban mengalokasikan sumber daya yang memadai untuk meningkatkan kinerja berbagai faktor tersebut. Faktor-faktor yang terletak pada kuadran ini merupakan prioritas untuk ditingkatkan. 
Ada dua macam metode untuk menampilkan data IPA, yaitu: pertama, menempatkan garis perpotongan kuadran pada nilai rata-rata pada sumbu tingkat kepuasan dan sumbu prioritas penangganan dengan tujuan untuk mengetahui secara umum penyebaran data terletak pada kuadran berapa. Pada bagian ini digunakan nilai rata-rata pada skala pengukuran tingkat kepuasan dan prioritas penanganan sebagai garis pemisah antar kuadran. Kedua, menempatkan garis perpotongan kuadran pada nilai rata-rata hasil pengamatan pada sumbu tingkat kepuasan dan sumbu prioritas penangganan dengan tujuan untuk mengetahui secara spesifik masing-masing faktor terletak pada kuadran berapa. Pada bagian ini digunakan nilai rata-rata hasil pengukuran tingkat kepuasan dan prioritas penanganan sebagai garis pemisah antar kuadran (Martinez, 2003).

Berikut prosedur berkaitan dengan penggunaan metode IPA: (1) penentuan faktor-faktor yang akan dianalisis; (2) melakukan survey melalui penyebaran kuesioner; (3) menghitung nilai rata-rata tingkat kepuasan dan prioritas penanganan; (4) membuat grafik IPA; (5) melakukan evaluasi terhadap faktor sesuai dengan kuadran masing-masing.

\section{HASIL DAN PEMBAHASAN}

Transformasi menggunakan method of successive interval (Hays, 1976). Metode tersebut digunakan untuk melakukan transformasi data ordinal menjadi data interval. Pada umumnya jawaban responden yang diukur dengan menggunakan skala likert (Lykert scale) diadakan scoring, yaitu pemberian nilai numerikal $1,2,3,4$, dan 5 . Setiap skor yang diperoleh akan memiliki tingkat pengukuran ordinal. Nilai numerikal tersebut dianggap sebagai objek dan selanjutnya melalui proses transformasi ditempatkan ke dalam interval.

Langkah-langkahnya adalah sebagai berikut: untuk setiap pertanyaan, hitung frekuensi jawaban setiap kategori (pilihan jawaban). Kemudian hitung proporsi setiap kategori berdasarkan frekuensi. Dari proporsi yang diperoleh, hitung proporsi kumulatif untuk setiap kategori. Tentukan pula nilai batas $\mathrm{Z}$ untuk setiap kategori. Lalu hitung scale value (interval rata-rata) untuk setiap kategori melalui persamaan berikut:

$$
\text { Scale }=\frac{\text { Kepadatan batas bawah - Kepadatan batas atas }}{\text { daerah at bawah batas atas - daerah dt bawah batas bawah }}
$$

Terakhir, hitung score (nilai hasil transformasi) untuk setiap kategori melalui persamaan:

$$
\text { score }=\text { scaleValue }+\mid \text { scaleValuemin } \mid+1
$$

Populasi dalam penelitian ini adalah semua mahasiswa aktif BINUS University, yaitu BINUSIAN 2011, 2012, 2013, dan 2014 yang berjumlah 19.101 mahasiswa. Jumlah detilnya dapat dilihat pada Tabel 2.

Tabel 2 Jumlah Mahasiswa Aktif BINUS University

\begin{tabular}{|c|c|}
\hline BINUS IAN & Jumlah Mahasiswa Aktif \\
\hline 2011 & 2,726 \\
\hline 2012 & 5,125 \\
\hline 2013 & 5,377 \\
\hline 2014 & 5,873 \\
\hline Total & $\mathbf{1 9 , 1 0 1}$ \\
\hline
\end{tabular}

Untuk menghitung jumlah sampel dari populasi tersebut, kami menggunakan rumus Isaac dan 
Michael. Dari tabel perhitungan sampel (Sugiyono, 2008) didapatkan bahwa apabila jumlah populasi 19.101 mahasiswa, jumlah sampelnya adalah 395 mahasiswa. Dengan taraf kesalahan 5\%, didapat hasil jumlah kuesioner yang harus dikumpulkan disesuaikan dengan jumlah populasi masing-masing angkatan. Rinciannya dapat dilihat pada Tabel 3 di bawah ini.

Tabel 3 Responden Kuesioner Valid

\begin{tabular}{|c|c|c|c|}
\hline Responden & Jumlah Responden & Kuesioner yang Disebarkan & Kuesioner yang Terkumpul \\
\hline Binusian 2011 & 2,726 & 75 & 60 \\
\hline Binusian 2012 & 5,125 & 125 & 106 \\
\hline Binusian 2013 & 5,377 & 130 & 111 \\
\hline Binusian 2014 & 5,873 & 135 & 118 \\
\hline Total & $\mathbf{1 9 , 1 0 1}$ & $\mathbf{4 6 5}$ & $\mathbf{3 9 5}$ \\
\hline
\end{tabular}

Teknik pengumpulan data yang digunakan adalah melakukan studi lapangan secara langsung dan sampling membagikan kuesioner kepada mahasiswa BINUS University. Data yang terkumpul diukur menggunakan statistical analysis tools seperti software SPSS 17.0 atau Microsoft Excel dan metode yang digunakan ialah multiple regression dan correlation model.

Kuesioner yang disebaran kepada responden berisikan pertanyaan-pertanyaan yang berkaitan dengan variabel understanding computer (X1), marketing communication (X2), interactivity (X3), content (X4), dan trust \& satisfaction (Y1). Berikut daftar dari pertanyaan yang diajukan melalui kuesioner persepsi mahasiswa tentang pengaruh i-branding pada website BINUS University terhadap loyalitas pelanggan, yang dapat dilihat pada Tabel 4 berikut ini.

Secara sederhana, kami melakukan uji validitas dan reliabilitas dengan membandingkan nilai korelasi ( $r$ hitung) dan Cronbach's Alpha yang dihasilkan dengan menggunakan bantuan software SPSS Statistic 17.0, dengan nilai dari $r$ tabel. Secara umum, ketentuannya adalah jika nilai korelasi $(r$ hitung) lebih besar dari $r$ tabel, pertanyaan tersebut dikatakan valid. Demikian juga jika Cronbach's Alpha lebih besar daripada $r$ tabel, variabel tersebut dapat dipercaya. Dikarenakan banyaknya pertanyaan dan jumlah variabel yang diuji serta melibatkan dua sudut pandang penilaian sekaligus (derajat kepentingan dan kenyaataan), skenario pengujian validitas dan reliabilitas dibagi ke dalam empat bagian, yaitu: uji validitas untuk derajat kepentingan, uji validitas untuk derajat kepuasan, uji reliabilitas untuk derajat kepentingan, dan uji reliabilitas untuk derajat kepuasan. Untuk $n$ sebanyak 30 dan $\alpha 5 \%$, nilai $r$ tabel adalah 0,361 .

Hasil uji validitas dapat dilihat pada Tabel 5 dan 6. Dari hasil uji korelasi dengan metode Pearson, semua nilai korelasi ( $r$ hitung atau Pearson's Correlation) lebih besar dari $r$ tabel $(0.098)$ dan nilai dari Sig (2-tailed) di bawah 0.05 maka H0 ditolak dan H1 diterima untuk hipotesis 1 sampai hipotesis 4. Hasil lengkap dapat dilihat pada tabel 7 di bawah ini.

Dari hasil pengujian regresi didapat bahwa Sig 0.000 menunjukkan angka positif (lebih kecil dari 0.05) sehingga $\mathrm{H} 0$ ditolak dan $\mathrm{H} 1$ diterima. Besarnya pengaruh variabel $\mathrm{X} 1, \mathrm{X} 2, \mathrm{X} 3, \mathrm{X} 4$ terhadap variabel Y1 dapat dilihat pada kolom Besar Pengaruh (dalam \%) dan data detilnya untuk hipotesis 5 sampai hipotesis 8 dapat dilihat pada Tabel 8 .

Variabel yang harus menjadi perhatian adalah variabel yang berada di kuadran 2 karena kepentingannya tinggi, tapi kepuasannya rendah. Variabel yang berada di kuadran 2 akan masuk dalam perbaikan prioritas 1 dan variabel yang masuk dalam kuadran 3 akan masuk dalam perbaikan prioritas 2. Data detil dapat dilihat pada Tabel 9 dan Tabel 10. 
Tabel 4 Daftar Variabel dan Pertanyaan

\begin{tabular}{|c|c|}
\hline \multicolumn{2}{|r|}{ Understanding Customer (X1) } \\
\hline $\mathrm{X} 1.1$ & Situs mempunyai jangkauan yang dapat diakses secara global/luas \\
\hline $\mathrm{X} 1.2$ & Situs mempunyai tampilan yang fleksibel / mudah dimengerti \\
\hline $\mathrm{X} 1.3$ & Situs mempunyai response time yang cepat \\
\hline $\mathrm{X} 1.4$ & Situs mempunyai inovasi terhadap teknologi \\
\hline $\mathrm{X} 1.5$ & Situs memberikan kenyamanan dalam mengakses www.binus.ac.id \\
\hline $\mathrm{X} 1.6$ & Situs mempunyai navigasi / shortcut untuk mempercepat perpindahan menu \\
\hline \multicolumn{2}{|r|}{ Marketing Communication (X2) } \\
\hline $\mathrm{X} 2.1$ & Situs mempunyai banner ads / iklan yang menarik \\
\hline $\mathrm{X} 2.2$ & Situs mempunyai tampilan yang menarik \\
\hline $\mathrm{X} 2.3$ & $\begin{array}{l}\text { Setiap promosi yang dilakukan BINUS University di berbagai media promosi selalu mencantumkan alamat } \\
\text { situsnya ( www.binus.ac.id ) }\end{array}$ \\
\hline $\mathrm{X} 2.4$ & Situs mempunyai nama brand / merek yang terpercaya \\
\hline $\mathrm{X} 2.5$ & Situs memberikan kemudahan untuk berdialog dalam email, chat room, newsgroup kepada mahasiswa \\
\hline $\mathrm{X} 2.6$ & Situs memberikan informasi yang memuaskan \\
\hline $\mathrm{X} 2.7$ & Situs menyediakan email yang dapat digunakan oleh mahasiswa \\
\hline \multicolumn{2}{|r|}{ Interactivity (X3) } \\
\hline $\mathrm{X} 3.1$ & Situs menyediakan blogs yang bermanfaat bagi mahasiswa \\
\hline $\mathrm{X} 3.2$ & Situs menyediakan RSS Feeds / mengirim informasi terbaru yang bermanfaat untuk mahasiswa \\
\hline $\mathrm{X} 3.3$ & $\begin{array}{l}\text { Situs memiliki online communities / social network seperti : facebook, Twitter, YouTobe, Flickr from } \\
\text { Yahoo }\end{array}$ \\
\hline \multicolumn{2}{|r|}{ Content (X4) } \\
\hline $\mathrm{X} 4.1$ & Situs memberikan informasi yang tepat sesuai yang dibutuhkan \\
\hline $\mathrm{X} 4.2$ & Situs menyediakan informasi yang sesuai dengan kebutuhan mahasiswa \\
\hline $\mathrm{X} 4.3$ & Situs menyediakan fitur-fitur yang mendukung proses pencarian informasi yang diperlukan \\
\hline $\mathrm{X} 4.4$ & Situs memberikan informasi yang memadai \\
\hline \multicolumn{2}{|r|}{ Trust \& Satisfaction (Y1) } \\
\hline $\mathrm{Y} 1.1$ & Apakah anda merasa puas terhadap situs www.binus.ac.id? \\
\hline Y1.2 & Apakah anda percaya terhadap situs www.binus.ac.id? \\
\hline Y1.3 & $\begin{array}{l}\text { Apakah Anda ingin untuk merekomendasikan BINUS University kepada teman, kerabat dan sanak } \\
\text { saudara? }\end{array}$ \\
\hline
\end{tabular}

Tabel 5 Hasil Uji Validitas

\begin{tabular}{|c|c|c|c|c|}
\hline \multirow[b]{2}{*}{ Variabel - Sub Variabel } & \multicolumn{2}{|l|}{ Kepentingan } & \multicolumn{2}{|l|}{ Kepuasan } \\
\hline & Valid & $\begin{array}{l}\text { Tidak } \\
\text { Valid } \\
\end{array}$ & Valid & $\begin{array}{l}\text { Tidak } \\
\text { Valid }\end{array}$ \\
\hline Understanding Customer (X1) & $\mathrm{X} 1.1, \mathrm{X} 1.2, \mathrm{X} 1.3, \mathrm{X} 1.4, \mathrm{X} 1.5, \mathrm{X} 1.6$ & - & $\mathrm{X} 1.1, \mathrm{X} 1.2, \mathrm{X} 1.3, \mathrm{X} 1.4, \mathrm{X} 1.5, \mathrm{X} 1.6$ & - \\
\hline Marketing Communication (X2) & $\mathrm{X} 2.1, \mathrm{X} 2.2, \mathrm{X} 2.3, \mathrm{X} 2.4, \mathrm{X} 2.5, \mathrm{X} 2.6, \mathrm{X} 2.7$ & - & $\mathrm{X} 2.1, \mathrm{X} 2.2, \mathrm{X} 2.3, \mathrm{X} 2.4, \mathrm{X} 2.5, \mathrm{X} 2.6, \mathrm{X} 2.7$ & - \\
\hline Interactivity (X3) & $\mathrm{X} 3.1, \mathrm{X} 3.2, \mathrm{X} 3.3$ & - & $\mathrm{X} 3.1, \mathrm{X} 3.2, \mathrm{X} 3.3$ & - \\
\hline Content (X4) & $\mathrm{X} 4.1, \mathrm{X} 4.2, \mathrm{X} 4.3, \mathrm{X} 4.4$ & - & $\mathrm{X} 4.1, \mathrm{X} 4.2, \mathrm{X} 4.3, \mathrm{X} 4.4$ & - \\
\hline Trust \& Satisfaction (Y1) & $\mathrm{Y} 1.1, \mathrm{Y} 1.2, \mathrm{Y} 1.3$ & - & $\mathrm{Y} 1.1, \mathrm{Y} 1.2, \mathrm{Y} 1.3$ & - \\
\hline
\end{tabular}

Tabel 6 Hasil Uji Reliabilitas

\begin{tabular}{|c|c|c|c|c|}
\hline \multirow[b]{2}{*}{ Variabel - Sub Variabel } & \multicolumn{2}{|c|}{ Kepentingan } & \multicolumn{2}{|c|}{ Kepuasan } \\
\hline & Reliabel & $\begin{array}{c}\text { Tidak } \\
\text { Reliabel }\end{array}$ & Reliabel & $\begin{array}{c}\text { Tidak } \\
\text { Reliabel }\end{array}$ \\
\hline Understanding Customer (X1) & $\mathrm{v}$ & - & $\mathrm{v}$ & - \\
\hline Marketing Communication (X2) & $\mathrm{v}$ & - & $\mathrm{V}$ & - \\
\hline Interactivity (X3) & $\mathrm{V}$ & - & $\mathrm{V}$ & - \\
\hline Content (X4) & $\mathrm{V}$ & - & $\mathrm{V}$ & - \\
\hline Trust \& Satisfaction (Y1) & $\mathrm{V}$ & - & $\mathrm{V}$ & - \\
\hline
\end{tabular}


Tabel 7 Hasil Uji Korelasi

\begin{tabular}{|l|c|c|c|}
\hline Hipotesa & $\begin{array}{c}\text { Pearson's } \\
\text { Correlation }\end{array}$ & $\begin{array}{c}\text { Tidak ada hubungan } \\
\left(\mathbf{H}_{\mathbf{0}}\right)\end{array}$ & $\begin{array}{c}\text { Ada hubungan } \\
\left(\mathbf{H}_{\mathbf{1}}\right)\end{array}$ \\
\hline Hipotesa 1 & 0,379 & Ditolak & Diterima \\
\hline Hipotesa 2 & 0,484 & Ditolak & Diterima \\
\hline Hipotesa 3 & 0,392 & Ditolak & Diterima \\
\hline Hipotesa 4 & 0,619 & Ditolak & Diterima \\
\hline
\end{tabular}

Tabel 8 Hasil Uji Regresi

\begin{tabular}{|l|c|c|c|c|c|}
\hline Hipotesa & $\mathbf{R}$ & $\mathbf{R}$ Square & $\begin{array}{c}\text { Besar } \\
\text { Pengaruh }\end{array}$ & $\begin{array}{c}\text { Tidak berpengaruh } \\
\left.\mathbf{( H}_{\mathbf{0}}\right)\end{array}$ & $\begin{array}{c}\text { Berpengaruh } \\
\left(\mathbf{H}_{\mathbf{1}}\right)\end{array}$ \\
\hline Hipotesa 5 & 0,396 & 0,157 & $15.7 \%$ & Ditolak & Diterima \\
\hline Hipotesa 6 & 0,550 & 0,302 & $30,2 \%$ & Ditolak & Diterima \\
\hline Hipotesa 7 & 0,393 & 0,154 & $15,4 \%$ & Ditolak & Diterima \\
\hline Hipotesa 8 & 0,686 & 0,470 & $47,0 \%$ & Ditolak & Diterima \\
\hline
\end{tabular}

Tabel 9 Hasil Gap Analisis

\begin{tabular}{|c|c|c|c|c|c|c|c|}
\hline \multirow{2}{*}{ Variabel } & \multicolumn{2}{|c|}{ Rata-rata } & \multirow{2}{*}{$\begin{array}{c}\text { Gap } \\
(\mathbf{Y}-\mathbf{X})\end{array}$} & \multicolumn{4}{|c|}{ Kuadran } \\
\hline & Kepentingan (X) & Kepuasan (Y) & & 1 & 2 & 3 & 4 \\
\hline $\begin{array}{l}\text { Understanding Customer } \\
(\mathrm{X} 1)\end{array}$ & 3.47 & 3.49 & 0.02 & $\mathrm{X} 1.1, \mathrm{X} 1.6$ & $\mathrm{X} 1.2$ & $\mathrm{X} 1.3, \mathrm{X} 1.5$ & $\mathrm{X} 1.4$ \\
\hline $\begin{array}{l}\text { Marketing Communication } \\
\text { (X2) }\end{array}$ & 3.55 & 3.56 & 0.01 & $\mathrm{X} 2.4, \mathrm{X} 2.5$ & $\mathrm{X} 2.3, \mathrm{X} 2.6$ & $\mathrm{X} 2.1, \mathrm{X} 2.2, \mathrm{X} 2.7$ & - \\
\hline Interactivity (X3) & 3.47 & 3.49 & 0.02 & $\mathrm{X} 3.3$ & - & $\mathrm{X} 3.1$ & $\mathrm{X} 3.2$ \\
\hline Content (X4) & 3.60 & 3.68 & 0.08 & $\mathrm{X} 4.3, \mathrm{X} 4.4$ & - & $\mathrm{X} 4.1, \mathrm{X} 4.2$ & - \\
\hline Trust \& Satisfaction (Y1) & 3.84 & 3.83 & -0.01 & - & Y1.2 & Y1.1 & Y1.3 \\
\hline
\end{tabular}

Tabel 10 Rangkuman Prioritas Perbaikan

\begin{tabular}{|c|c|c|c|}
\hline Variabel & $\begin{array}{c}\text { Faktor-faktor yang sudah } \\
\text { optimal }\end{array}$ & \begin{tabular}{|c|} 
Faktor-faktor yang segera \\
ditingkatkan pada prioritas 1
\end{tabular} & \begin{tabular}{|l} 
Faktor-faktor yang segera \\
ditingkatkan pada prioritas 2
\end{tabular} \\
\hline \multirow{3}{*}{$\begin{array}{c}\text { Understanding } \\
\text { Customer } \\
\text { (X1) }\end{array}$} & Jangkauan akses (X1.1) & \multirow{3}{*}{ Tampilan fleksibel (X1.2) } & \multirow{2}{*}{ Response time (X1.3) } \\
\hline & Inovasi teknologi (X1.4) & & \\
\hline & Navigasi (X1.6) & & Kenyamanan (X1.5) \\
\hline \multirow{3}{*}{$\begin{array}{c}\text { Marketing } \\
\text { Communication } \\
\text { (X2) } \\
\end{array}$} & Brand /merek yang terpercaya & \multirow{2}{*}{ Pencantuman alamat situs (X2.3) } & Banner ads /iklan (X2.1) \\
\hline & (X2.4) & & Tampilan menarik (X2.2) \\
\hline & Kemudahan berdialog (X2.5) & Pemberian informasi (X2.6) & Penyediaan email (X2.7) \\
\hline \multirow{2}{*}{$\begin{array}{l}\text { Interactivity } \\
\quad \text { (X3) }\end{array}$} & Penyediaan RSS Feeds (X3.2) & \multirow[b]{2}{*}{-} & \multirow[b]{2}{*}{ Penyediaan blog (X3.1) } \\
\hline & $\begin{array}{l}\text { Online Communities / Social } \\
\text { Network (X3.3) }\end{array}$ & & \\
\hline \multirow{2}{*}{$\begin{array}{l}\text { Content } \\
\text { (X4) }\end{array}$} & Fitur pencarian informasi (X4.3) & \multirow[b]{2}{*}{-} & Informasi yang tepat (X4.1) \\
\hline & Informasi yang memadai (X4.4) & & Informasi yang sesuai (X4.2) \\
\hline $\begin{array}{c}\text { Trust \& } \\
\text { Satisfaction } \\
\text { (Y1) }\end{array}$ & Rekomendasi (Y1.3) & Kepercayaan (Y1.2) & Kepuasan (Y1.1) \\
\hline
\end{tabular}

\section{PENUTUP}

Berdasarkan hasil pembahasan yang telah dibahas, maka penelitian ini dapat disimpulkan sebagai berikut: (1) Dari hasil pengujian analisis korelasi dan regresi, dapat disimpulkan bahwa terdapat hubungan yang positif dan cukup signifikan antara $i$-branding yang dijabarkan oleh variabel 
understanding customer, marketing communication, interactivity, dan content dengan customer loyalty yang dijabarkan oleh variabel trust \& satisfaction; (2) Dari hasil analisis korelasi didapat seluruh nilai $\mathrm{r}$ variabel lebih besar dari $\mathrm{r}$ tabel (0.098), sehingga semua hipotesis satu $\left(\mathrm{H}_{1}\right)$ diterima dan hipotesis nol $\left(\mathrm{H}_{0}\right)$ ditolak; (3) Dari analisis regresi didapat seluruh semua hipotesis satu $\left(\mathrm{H}_{1}\right)$ diterima dan hipotesis $0\left(\mathrm{H}_{0}\right)$ ditolak; (4) Dari gap analisis, diketahui masih ada variabel yang perlu ditingkatkan pada prioritas 1 dan prioritas 2 .

Rekomendasi yang diusulkan kepada BINUS University untuk perbaikan dalam prioritas utama adalah: (1) situs harus memiliki tampilan yang fleksibel karena dengan tampilan yang fleksibel akan membantu pengguna mengakses situs dengan mudah; (2) pencantuman alamat situs pada semua media promosi BINUS University karena hal ini akan membuat pelanggan lebih mudah mengingat alamat situs; (3) situs harus memberikan informasi yang memuaskan karena dengan informasi yang memuaskan akan menarik pengguna untuk membuka situs kembali; (4) meningkatkan kepercayaan terhadap situs www.binus.ac.id karena kepercayaan akan menghasilkan loyalitas yang lebih tinggi.

Sedangkan rekomendasi untuk perbaikan dalam prioritas kedua adalah: (1) situs harus memiliki response time yang cepat, karena dengan response time yang cepat akan dapat membantu pengguna dalam membuka situs; (2) situs harus memberikan kenyamanan dalam mengakses www.binus.ac.id karena hal ini akan menarik dan memudahkan pengguna untuk mengakses situs BINUS University; (3) situs harus memiliki banner ads/iklan yang menarik karena dengan banner ads yang menarik tanpa mengganggu pengguna dalam mengakses situs akan membuat pengguna lebih tertarik dengan situs; (4) situs harus memiliki tampilan yang menarik karena dengan tampilan yang menarik akan membuat pengguna mau untuk terus mengakses situs; (5) situs harus menyediakan email yang dapat digunakan oleh pengguna karena dengan adanya fasilitas email yang dapat digunakan oleh pengguna akan membuat pengguna merasa terfasilitasi; (6) situs harus menyediakan blogs yang bermanfaat bagi pengguna karena dengan adanya fasilitas blogs yang dapat digunakan oleh pengguna, akan membuat pengguna merasa mendapat informasi yang berguna, up-to-date dan mudah didapat; (7) situs harus memberikan informasi yang tepat karena dengan pemberian informasi yang tepat akan memuaskan pengguna dalam mengakses situs; (8) situs harus menyediakan informasi yang sesuai dengan kebutuhan pengguna karena dengan penyediaan informasi yang sesuai dengan kebutuhan pengguna akan membuat pengguna merasa terpenuhi kebutuhannya atas informasi; (9) meningkatkan kepuasan terhadap situs www.binus.ac.id karena kepuasan akan meningkatkan loyalitas.

\section{DAFTAR PUSTAKA}

Aaker, D.A. (1991). Managing Brand Equity. New York: The Free Press.

Anderson, R. E. \& Swaminathan, S. (2011). Customer satisfaction and loyalty in e-markets: a PLS path modeling approach. Journal of Marketing Theory and Practice, 19(2), 221 - 234.

Brandt, D.R. (2000). An "outside-in" approach to determining customer-driven priorities for improvement and innovation. White Paper Series, 2.

De Chernatony, L. \& McDonald, M. (1992). Creating Powerful Brands. Oxford: Butterworth Heinemann.

Doyle, P. (1998). Marketing Management and Strategy (2nd ed.). Harlow: Prentice-Hall.

Hays, W. L. (1976). Quantification in Psychology. New Delhi: Prentice Hall. 
Ibeh, K. I. N., Luo, Y. \& Dinnie, K. (2005). E-branding strategies of internet companies: some preliminary insights from the UK. Journal of Brand Management, 12(5), 355-362.

Kenney, M. \& Curry, J. (1999). E-commerce: configuration. Economy Paper 2, California: University of California, Berkeley, CA.

Latu, T.M., \& Everett, A. M. (2000). Review of Satisfaction Research and Measurement Approaches. Departement of Conservation. Wellington. New Zealand.

Martinez, C.L. (2003) Evaluation Report: Tools Cluster Networking Meeting \#1. Arizona: CenterPoint Institute.

Simmons, G. J. (2007). "I-Branding": developing the internet as a branding tool. Marketing Intelligence \& Planning, 26(6), 544 - 562.

Sugiyono. (2008). Metode Penelitian Bisnis. Bandung: CV Alfabeta. 